\title{
Phenomenology and Ontology in the Lukácsian Concept of Labor
}

\author{
Manuel Alejandro Bonilla Bonilla \\ Faculty of Management, University Luis Vargas Torres, Santo Domingo, Ecuador
}

Email address:

mabonillab5@gmail.com

To cite this article:

Manuel Alejandro Bonilla Bonilla. Phenomenology and Ontology in the Lukácsian Concept of Labor. International Journal of Philosophy. Vol. 7, No. 2, 2019, pp. 55-61. doi: 10.11648/j.ijp.20190702.12

Received: February 22, 2019; Accepted: April 8, 2019; Published: April 29, 2019

\begin{abstract}
This article attempts to reassess the evaluation of one of the most crucial concepts in the philosophy of the hungarian philosopher Georgy Lukács, namely, the concept of labor. It discusses how, as a result of his own philosophical evolution, Lukács developed two different approaches in his investigation about the fundamental categories that comprise social reality. One approach -developed in his young years- discusses the social categories in relation with the historical development of the subjective consciousness, in other words, it deals with the relationship between 'historical world' and 'human consciousness'. The philosophical evolution of the young Lukács made him understand that relationship according to the theoretical framework that Hegel developed in the Phenomenology of the Spirit. The second approach -developed in the marxist period of Lukács- assumes the social categories as 'ontological concepts' that explain the fundamental socioeconomical elements of the meta-categorial system that is the human world. In particular, the article analyzes such duality of approaches in regards of the social category of labor. It shows how the interaction between these two approaches influences the discussion of the category of labor in the context of advanced capitalism, and how it affects the lukácsian understanding of social categories in general.
\end{abstract}

Keywords: Labor, Ontology, Phenomenology, Aesthetics, Ethics

\section{Introduction}

The philosophical activity of the late Lukács is characterized by the conscious attempt to advance in the realization of systematic projects of marxist orientation that discussed fundamental areas of philosophy. Lukács considered that marxist philosophy was capable of producing works of theoretical nature that were in line with the philosophical developments contained in Marx's work, and that, starting from the outlines given by Mark and Engels, marxist philosophers could accurately discuss the foundations of the different areas of human thought and action [1]. Aesthetics, ontology, and ethics, the three traditional fields the Lukács of the last period was occupied with, share the attempt to lay a marxist foundation of social reality with a comprehensive and generalizing focus. This intention is so pronounced that the last years of the Hungarian philosopher's life manifested a continuous mobility in the intellectual work devoted to these respective areas. According to the philosophical vision and methodical procedure of the late Lukacs, it would not be possible to accurately establish general philosophical postulates of one field without implicating the general philosophical postulates of the other [2]. In particular, the ontological perspective -the attempt to find the philosophical principles of reality with a marxist world view- prompted Lukacs to confront the idea of a systematic theory of aesthetics, and finally, we know that Lukács understood his work about the ontology of the Social Being as a form of prolegomena to problems that were to be discussed in a later marxist ethic [3]. In the Hungarian preface to the reissue of his article "Mi way to Marx", Lukács tacitly asserted that aesthetics is an organic part of a more comprehensive ontology of social being [4]. This intimate connection of the first part of the aesthetics, the Ontology of the Social Being and the sketches on Ethics, would not exist without this 'ontological social orientation' characteristic of the philosophy of the late Lukács [5]. But, as we will try to prove, that ontological orientation of the late marxist years is also compensated and complemented by 
another phenomenological approach that Lukacs have already developed in previous philosophical works, specifically, those works of his so called idealistic 'young period'.

\section{Main Body}

According to the late Lukacs, the ontology as a philosophical field incorporates all the general categories that constitute the social reality, so that principles of, for example, ethics and aesthetics will fall within the framework of an ontological theory. On the other hand, Lukács was aware that the ontological categories that correspond to the aesthetic or the ethic dimension have a specific concreteness in each moment of the historical process; he also remarked the influence of such concretion for the way in which each dimension is articulated within the complex framework of social reality. The analysis of how the ontological categories are concretized in the historical evolution of the aesthetical and ethical, and in particular, the analysis of how historical consciousness reacts and influences to such concreteness, is as we will see- a philosophical inquiry in which Lukács made an extensive use of a particular type of phenomenology.

In order to present the interaction between the ontological and the phenomenological, it is necessary to distinguish first the phenomenological and the ontological approach in the work of Georg Lukács. The Italian philosopher Antonino Infranca has made important contributions about this issue in several texts and articles related to the topic of Lukacs' Marxism [6]. He has convincingly shown that the analysis in the book History and Class Consciousness -the apex of the 'young period', and a book that Lukacs himself later called a Hegelian work- is not in direct contradiction to the analysis of the much later ontological discussions present in a book like Ontology of the Social Being. Some previous lukácsian studies have revealed sensitive correspondences between investigations that are present in History and Class Consciousness and certain arguments of the Ontology of the Social Being [7], but Infranca has proven that those manifest correspondences are significant [8]. The fundamental concept of Labor is addressed in each respective book through a distinctive methodological approach that produces some precise correspondences between works, but also many differences in argumentation and exposition. We argue, following Infranca, that the duality of approach corresponds on one hand to the predominance of a phenomenological perspective -in History and Class Consciousness-, and secondly to the existence of an ontological perspective -in Ontology of the Social Being -. Between the two methodologies the textual analysis verifies a logical sequence, expressed in the actual chronological order of publication of History and Class Consciousness and Ontology of the Social Being.

\subsection{The Phenomenological Approach}

As it is known, a central aim of the juvenile History and Class Consciousness is to follow, in a materialist-historical way, the Hegelian 'science of the experience of the conscience'. Lukacs had at the time attempted to describe the genesis of the consciousness of the proletariat on the basis of a philosophical and historical outline cut on the model of the Phenomenology of the Spirit, but in this enterprise he used a particular scheme that is no longer proper deployment of the self-consciousness as in Hegel, but rather the dialectic and immanent development of social-historical categories. The dialectical movement of the categories, which always is expressed in a certain historical tendency placed in a reflexive relationship with the socio-economic dynamics of society, is the key concept to reconstruct the evolution of the 'forms of social conscience'. According to Lukács, the conscience of the individual intervenes in the final moments that lead to the objective concretization of a category. Thus, the movement of the categories it's the horizon in which the changes of the historical consciousness of social groups are ultimately framed and actualized. History and Class Consciousness' aim is to investigate the connection of individual consciousness with all the procedural framework that corresponds to the categories of capitalist society.

In his analyzes and different arguments about the relationship between consciousness and the social world, Lukács verifies the central importance of the social category of "reification" (Verdinglichung). According to the historical evolution of the categorial relations, the exchanges between individuals that are characterized by reifying social relations tend to acquire a predominant role in the march of society and in the genesis of the different forms of social consciousness. Thus, studying the social phenomenon of reification, Lukács discovers that the genesis of the consciousness of the proletariat follows the structure of the process of alienated labor, which assimilates the worker with the object of the work produced. This means that the life of the worker is intervened by the fetishistic character of the commodity, which mediates the entire process of production and distribution in advanced capitalism. The influence of the categorical determinations of alienated labor in the consciousness of the worker, determines that it's the worker's consciousness that expresses the most direct, fruitful and undefined relation with respect to the product of alienated labor, or in other words, with the 'object' as it is created and experienced in the capitalist society

The numerous and intensive analyzes carried out by Lukács to sustain the predominance of the categories of reification and estrangement in the process of labor, and the consequences that this has for the evolution of the historical social tendencies of advanced capitalism, constitute the central part of the book History and Class Consciousness. Here we point out that the analysis of the genesis of the consciousness of the worker through the structure of alienated labor supposes the postulation of a phenomenology of the experience of the consciousness; which is devoted, specifically, to an analysis of the concrete and current conditions in which this process it's done.

One the other hand, such phenomenology, like the Hegelian phenomenology, presupposes the emergence of a 
strictly ontological dimension, even when it strives to depart from the immediate historical being of the labor process [9]. The phenomenological argumentation appears as a step logically prior to an ontological argumentation, which would be the one in charge of finding what are the fundamental categories that operate in the social phenomenon of alienation. The dialectic of essence and phenomenon found in Hegel assumes that the most immediate determinations that the consciousness knows are just a first stage in the path that consciousness goes through until the capture of the ample complex of determinations that crystallizes in each social phenomenon. Therefore, it would not be possible to obtain an adequate diagnosis of the determinations of the social being, until the determinations that exert a more direct and immediate influence on the conscience are properly studied and structured. The philosophical step from a phenomenal appearance to a complex processual totality, is the line that conducts to the ontological argumentation.

This condition is actually corroborated by the philosophical development of Lukács; even when he abandoned the idealistic approach of History and Class Consciousness and assumed a materialistic world view in accordance with marxist philosophy. The mediations involved in the dynamics of the consciousness are still present in the late systematic works, specifically, in Ontology of the Social Being, just that, strictly speaking, they exist as a tacit postulate, so that the theory of social being social can specify, without subsequent reconstructions, the appropriate starting point for an ontological exposure of the object.

\subsection{Towards an Ontological Approach}

The textual analysis shows how the difference of approach results in differences in the exposure and argument. In particular, the exposition in History and Class Consciousness lacks the ontological-genetic analysis of labor that is carried out in the text of Ontology of the Social Being, so that the phenomenon of the alienation is only addressed in its 'subjective dimension', leaving aside the different spaces of social reality that have their genesis in the objectification of the human essence [10]. This causes that the same phenomenon of the alienation is only understood partially, although not falsely. History and Class Consciousness can be read therefore, in order to complete it, and to reform it, as an antecedent and seminal chapter of the Ontology of the Social Being. One might think -in this respect- of the relationship between the Phenomenology of the Spirit and the Science of Logic. Like the Phenomenology of the Spirit, History and Class Consciousness shows operating, in concrete historical moments, the immanent dialectical movement of notions and categories in the background of the development of the "forms of consciousness"; whereas in the Science of Logic the concepts are more than anything exposed, supposing already a concrete historical movement that is not the center of the argumentation, assuming an analytical and generalizing point of view; something that is similar to what happens in the Ontology of the Social Being. But while the Phenomenology of the Spirit could be subsumed in the system of the Hegelian philosophy -we remember that Hegel incorporated it as chapter of the Encyclopedia of the Philosophical Sciences -, the subjective approach to the phenomenon of self-estrangement of History and Class Consciousness, which focuses unilaterally on the subjective conditions of the social process that justifies alienation, makes postulates that always must be contrasted and completed with the objectivist and encompassing perspective of Ontology of the Social Being.

In Ontology of Social Being the ontological presuppositions of the historical essence of 'social being' are made explicit. The category of reification is understood as an element of the conceptual scheme formed by the processes of objectification (Vergegenständlichung) and alienation (Entäusserung) of the human genericity (Gattungsmäßigkeit). These concepts are considered fundamental categories of the historical process of self-constitution of mankind in history. They make possible to explain the crucial moments that are operative in the transformation of nature and social environment, and they allow to conceptualize the increasingly complex construction of a social objective world through labor.

The category of objectification expresses the set of objective determinations that are the result of the continuous construction and expansion of the human capacity to transform nature and the social world, and, therefore, the human capacity to create the very conditions of their existence. The category of alienation indicates the determinations that correspond to the general phenomenon that, whenever it transforms nature and the social world, mankind carries out the adaptation of its internal subjectivity to the external conditions of the productive process. Lukács argued that mankind creates increasingly complex social objectivities according to the development of its productive social forces, and that in this process, it transforms its own subjectivity -within his intellectual, emotional and physical faculties- based on existing objectivities. The objectification / alienation pair reveals that mankind, as a subject, continualy objectifies its social world at the same time as it continually transforms its own nature as 'subject of objectifications' [11].

In its abstracted relation with objectification, the alienation appears as a distinctive ontological category of social being and is originally neutral. Both for Lukács and for Marx, although labor develops the intellectual, emotional and physical faculties of the subjects, at the same time it uproots the particular individual from those, driving only the fragmentary and highly specialized qualities that correspond to the division of the labor in each worker. Hegel had postulated to overcoming of the distance between subject and its potentiality that appears in the process of labor in a very conceptual manner, postulating its superation in the encompassing perspective of the Absolute Spirit; Marx and Lukács criticized such an overcoming as abstract, and finally, fictitious. For Lukács, the true unfolding and fulfillment of the alienation entails the re-appropriation of the human faculties and potentialities in a process that is oriented towards the development of a complete personality, by which 
the subjective qualities as a whole are re-applied to the cultivation of the individual.

The lack of that re-appropriation in the individual, that is, the lack of an update by the subject of their human capacities in the various facets that involve their actions, is designated with the name of estrangement (Entfremdung) [12]. In contemporary capitalism, estrangement, understood as the lack of re-appropriation in different degrees and modes, is a common feature of all socio-economic activities. As part of the investigation on questions related to the estrangement of the subjectivity, appears the social phenomenon of reification, a pivotal thematic in the marxist critic of modern society. The different approximations in Ontology of Social Being to the problem of estrangement correspond to a phenomenological analysis about the mental effects of the category of commodity fetishism. This stage of the discussion is the moment when the categories abstracted by the ontological approach are then dissolved into historical concrete relations between the consciousness and the social reality [13]. The chapter of Ontology of the Social Being devoted to estrangement advances on the general aproaches that would form part of such research, taking as general reference the ontological categories of labor, objectification and alienation.

If estrangement can be understood as a possibility allowed by the inequality existing between the process of social objectification and the alienation of subjectivity, the concept of reification allows us to elucidate a basic characteristic of the immediate relationship between the estranged consciousness -that is, one that is lacking a real reappropriation-, and the social world. For such consciousness, the social relations appear as 'things given' that are independent of the intentions and possible transformations of the subject. Even the conscience, as part of that relation, appears to itself as cloistered in fixed determinations. The starting point of the possibility of reification lies in the fact that, at the level of the experience of daily life, the external natural objects with which the consciousness has an immediate relationship are manifested with the 'character of things' (Dinghaftigkeit). In a primitive phase of knowledge, all objects are presented with determinations that refer to the character of 'things', even those phenomena that captured by the consciousness cannot be identified with concrete material realities (for example, an abstractly learned idea, a social relation, an ethical principle). Although the flow of thought leads to the overcoming of that abstract and immediate consideration of the contents of the experience, a characteristic of the contemporary social reality is that the consciousness of the individual it's seen in relationships that sustain the appearance of 'given thing' for all the phenomena. As a result of the influence of the 'commodity fetishism' in the economic processes, by which it's remarked in the objects those of its determinations that are most operative in the production and exchange of commodities, the men and women consider their entire social reality through the filter of abstract economic determinations. Insofar as this is a subjective tendency that does not correspond to the true processual nature of social phenomena, it is possible to identify it as an expression of the inability of the individual subjectivity to re-appropriate their potential and faculties in an integral diary experience, which prevents them from actualize the state of evolution of the human 'generic essence' (Gattungsmäßigkeit). The alienation of the subjectivity that stops itself at the 'character of thing' of the objects, phenomenologically reveals the influence of the commodity fetishism on the dynamics of social relations, for which reason the concept of reification always points to the social relations that promote such appearance. This is why Lukács tended to use the concept of reification in connection with the concept of fetishization, in the context of pervasive alienating and reifying social relations.

\subsection{Relation Between Phenomenological and Ontological Approaches}

In History and Class Consciousness the distinction between objectification, alienation and reification is not clear, since a connection of the phenomenological analysis of the 'figures of consciousness' in advanced capitalism with the ontological categories of the social being was missing. However, it can be affirmed that the category of reification of History and Class Consciousness, insofar as it shows the tendency of the consciousness that suffer the effects of the fetishization to pay attention to the character of appearance of the objects, has its argumentation supposed in the scheme for the appearance of reification that is proposed the Ontology of the Social Being. The phenomenological advances on the concrete manifestations that the estrangement acquires in advanced capitalism effectively recall the analyzes about the consequences of fetishization in History and Class Consciousness. From this it can be pointed out that the phenomenological perspective is a step for the correct ontological treatment of the fundamental categories of social being and labor, and that the ontological argumentation is already 'presupposing' the results of a phenomenological investigation, moreover that it completes them.

Phenomenological research shows that, given that economic-social categories are what drive the dynamics of the constitution of the social reality, the scheme that is adopted in the mode of production always extends itself to the other different dimensions of the social. This means that the commodity fetishism, a phenomenon that has its genesis in purely economic moments and that reaches its greatest concreteness in the advanced capitalism, extends its influence to the different interpersonal relationships and consolidates a reified appearance of the categories. The subjects relate to each other with the 'commodity fetishism' as mediation, in the same way that all social objectivities are considered according to determinations that correspond to the process of production and exchange of goods. This has as a result that the subjects and the objective social facts are not considered as essentialities with a changing historical mobility, but as finished products, as static and definitive facts where economic determinations stand out and are imposed on the 
conscience as the essential. It exists a fragmentary relationship between the different individuals that are part of society, and between these individuals and the social whole. As a result of this fragmentary relationship with itself and with society - a demonstration of the lack of an integral reappropriation of alienated individuality- the objects of experience always emphasize their character of being a 'thing', whether it be about other men or different social phenomena.

Reification is then transformed into a mediation that goes through the individual's relationship with the human possibilities that emerge in the course of the human generic essence, ultimately structuring the process of historical objectification of that essence. The reification becomes a natural instance of living, which the consciousness of individuals receives, and in front of which they behave. In the subjective horizon of History and Class Consciousness, which seeks to show the "figure of consciousness" corresponding to advanced capitalism, Lukács could affirm that reification is the phenomenal form of capitalist society for all social groups that develop their life in it. Research about the social influence of reification leads to an analysis of the capitalist division of labor, an analysis that, phenomenologically, it is carried out in History and Class Consciousness, and ontologically, in the section of Ontology of the Social Being that is dedicated to the category of estrangement.

\subsubsection{Phenomenology and Ontology of the Social Category of Labor}

Throughout the process of production, a particular division of labor is configured, which characterizes the capitalist mode of production. The individuals in each parcel of the division of labor, in their interaction with other men and with the social reality, highlight the determinations that correspond to to their isolated position and take these determinations as definitive facts; which in turn consolidates the partialization of subjective experience and the manifestation of abstract determinations that have an apparent universality.

One of the central points of the Lukácsian phenomenological argumentation is that the fragmented and alienated relationship of the worker with the social whole and with the product of his work is initially generated in the field of manual labor, then, the predominance of the category of the commodity extends these effects to the intellectual labor. Lukács analyzes the effects of such a state of affairs in the intellectual labor, specifically in the passages of his work that deal with the characteristic bureaucracy of capitalism. These analyzes show that the individual consciousness always reproduces, in its own sphere of action and thinking, the consequences of the predominance of the category of the commodity as an instance of mediation between reality and consciousness that becomes effective for all social activity. Investigating the condition of this state of affairs requires mentioning the effects, among others, of rationalization, the professional hyper- specialization, the ramification of intellectual activity, the orientation towards the measurable and quantifiable of the human sciences, all of which are characteristic phenomena of late capitalism [14]. In various writings of literary criticism and sociology of literature Lukács analyzed some of the effects that a consciousness subjected to the influence of 'commodity fetishism' has for the realization of intellectual products.

The phenomenology of consciousness in the field of intellectual work requires a complex set of socio-historical analyzes; for our subject is enough to ask ourselves this question: what does it mean for intellectual work the influence of alienating social relations? To answer this question we can remember that, according to Lukács, the categories that make up the Social Being are all historical and procedural, and that in each historical moment the determinations and relationships between the determinations that make up the categories can change. For Lukacs the categories have always a certain historical concreteness; and strictly speaking, the current phenomenal and immediate configuration of social categories is a historical contingency in which that concreteness occurred; that state of affairs can change at another moment in history. The historical and procedural nature of the categories reveals Lukács' need to clarify the concrete conditions -always subject to the evolution of economic formations - in which the relationship of consciousness with the world are articulated, and, likewise, the need to show the apparent form that, for the alienated subject, takes this historical relation.

Specifications like these make it possible to narrow down the conceptual horizon of the previously postulated question: what characterizes an intellectual work that becomes effective with the 'immediate' predominance of the influence of the commodity fetishism for all the social process? In principle it can be said that in the Lukácsian system all intellectual activity involves the mediation of determinations corresponding to the predominant categories in the productive dynamic of capitalism. For example, those determinations that Lukács identified in his analysis of the intellectual labor in History and Class Consciousness. According to him, there is a peculiar relation of the conscience with the objective reality that consists in the act of transplanting, to the plane of the intellectual activity, determinations that conform the daily life transited by the phenomenon of reificatory social relations.

But that is just one scenario. For Lukács, consciousness has several instances of relation to the objective reality, ranging from the most immediate relationship proper to the economic activity of everyday life to a relationship in which numerous methodological and theoretical measurements are involved, particularly in the case of science of economic criticism practiced by Marx in The Capital. In the field of everyday life we can distinguish occurrences that correspond to the most direct relationship with the logic of economic production and reproduction, in particular those that correspond to the relationship with the other objective complexes of life that surpass and exceed the economic. In the first case the immediate, fragmentary and partial relation 
of the individual conscience with the determinations of the economic categories is identified, in such a way that the perception of all economic matters is allowed to be driven by the phenomenal appearance of the determinations. In a second case, we arrive to the recognition that there is a wide field of relations with the objective realities that take shape in various instances of the ordinary life, that actively 'surpass' the economic [15]. The 'subjective orientation' of the late Lukácsian ontology recognized that these instances are related to the fact the individuals retain the capacity to actualize and express the faculties and potentialities of the human generic essence that have been developed through the historical configurations of labor.

\subsubsection{Ontology and Phenomenology of Everyday Life}

To the possibility of superation of estrangement Lukács referred when, in his literary criticism of modernist authors, he considered that these writers emphasized the emptiness of modern societies, instead of showing the complexity and variety of determinations in the daily life of each individual. In the Ontology of the Social Being some of these instances proper of common life are shown with descriptive abundance. In that book we will notice the fact that, according to Lukács, although it is true that mankind can have inverted awareness of the categories with which relates in the exercise of the economic process, the other complex objectives of the individual's life (the family, ethics, law, etc.) allow potentially a worldview wider and more complex than that which is favored by the deforming effects of the economic predominance of the commodity fetish [16]. This fertile and complex level of relations of the conscience with the social objectivities becomes effective in the course of the daily life of the individuals. On this basis, the intellectual activity can proceed to elaborate the determinations of life in a way that highlight a more liberalized relation of the consciousness with the social whole; such a development, we find, for example, in the intellectual activity of the great artists. These forms of 'ascent from the particularity' are not an extraordinary achievement attainable solely by great personalities; instead, they are a 'force motrice' of human history [17], reachable by any normal individual.

Lukács emphasized the fact that ultimately is the subject that decides the concreteness of a social category; he recognized the importance of economical and material conditions, but also noted that in those objective conditions the subject is always involved as the agent that ultimately actualize the material tendencies or processes [18]. Thus, the ontological social categories, even the most determinant in a certain historical mode of production, can have different and contingent concretizations as a result of different subjective and objective factors related to the daily life of the individual. The influence of the historical concretion for the individual and social consciousness -and vice versa- can be determined by phenomenological studies that elucidate the relation between a given 'historical reality' and the everyday life consciousness of the subjects.

\section{Conclusion}

This relationship between a phenomenology of the modern consciousness in advanced capitalism, and an ontology of Social Being, allows Lukács to frame the nature and historical realization of the defining categories of the social whole. It also shows how the ontological category of labor acquires fetishizing characteristics due to a particular relationship of modern consciousness with the object that is connatural to the capitalist mode of production. But, by showing the fetishization as the result of a phenomenological analysis, i.e. as a result of an analysis of the forms of modern consciousness, it shows the particular contingency of fetishization: the ontological category of labor can be realized in other forms of consciousness-object relationship that are different from those discovered by the phenomenological analysis of consciousness in advanced capitalism -as it existed in ancient societies, for example, or as it may exist in the future-. This relationship also shows that there are instances, like the intellectual work in the aesthetic field, where consciousness may exceed the contingent limitations discovered by the phenomenological analysis of the effects of commodity fetishism, and the subject can assume a liberating -and ontologically groundedrelationship with the object.

\section{References}

[1] G. Lukács, G. Gelebtes Denken. Eine Autobiographie im Dialog. Frankfurt, 1980, p. 235.

[2] N. Tertulian. "Lukács Ontology". In: T. Rockmore (Ed.). Lukács Today. Essays in Marxist Philosophy. Dordrecht: Reidel Publishing Company, 1988, p. 243-5.

[3] G. Lukács, G. Zur Ontologie des gesellschaftlichen Seins. Darmstadt and Neuwied: Luchterhand, Vol. 1, 1984. p. 664.

[4] D. Zoltai. "The Reconstructible chief work": Notes on Lukács late aesthetic synthesis. In: L. Illés; F. József (Eds.), Hungarian studies on Lukács. Budapest: Akadémiai Kiadó, 1993. Vol. 2, p. 536.

[5] F. Benseler F. "Nachwort des Herausgebers". In: G. Lukács. Zur Ontologie des gesellschaftlichen Seins. Darmstadt and Neuwied: Luchterhand, 1986. p. 737.

[6] A. Infranca. Trabajo, Individuo, Historia. El concepto de trabajo en Lukács. Buenos Aires: Herramienta, 2005.

[7] F. Benserler. "Zur 'Ontologie' von Georg Lukács". In: U. Bembach, G. Trautmann (Eds). Georg Lukács. Kultur - Politik Ontologie. Opladen: Westdeutscher Verlag, 1987, pp. 253.

[8] A. Infranca. "Fenomenologia y Ontologia en el Marxismo de Lukács". In: A. Infranca, M. Vedda (Eds.). Gÿorgy Lukács: Ética, Estética y Ontología. Buenos Aires: Colihue, 2007, p. 153-4.

[9] R. Fortes. "Las categorías de objetivación (Vergegenständlichung), enajenación (Entäuserung) y alienación (Entfremdung) en el último Lukács". In: A. Infranca; M. Vedda (Comps), La alienación; historia y actualidad. Buenos Aires: Herramienta, 2012, p. 70. 
[10] G. Lukács. "Vorwort". In: Frühschriften II: Geschichte und Klassenbewusstsein. Darmstand and Neuwied: Luchterhand, 1977, p. 19-20.

[11] R. Fortes. As Novas vias da Ontologia em György Lukács. Saarbrücken: Novas Edicoes Academicas, 2013, p. 214-229.

[12] A. Giesbert. "Menschwerdung. Der Begriff der Entfremdung beim späten Lukács". In: C. Bauer, B. Caspers, J. Werner (Eds.). Georg Lukács. Totalität, Utopie und Ontologie. Duisburg: Universitätsverlag Rheim-Ruhr Duisbug, 2012, pp. 93-122.

[13] G. Lukács, G. Zur Ontologie des gesellschaftlichen Seins. Darmstadt and Neuwied: Luchterhand, v. 2, 1986. p. 125ss, $219,227,302$.

[14] K. Terezakis. "Living form and living criticism". In: M. Thompson (Ed.). Lukács reconsidered. Critical Essays in Politics, Philosophy and Aesthetics. London: Continuum, 2011, p. 224.
[15] W. Jung. "Zur Ontologie des Alltags. Die späte Philosophie von Georg Lukács". In R. Dannemann, W. Jung (Eds.). Objektive Möglichkeit. Beiträge zu Georg Lukács' "Zur Ontologie d"es gesellschaftlichen Seins". Opladen: Springer Fachmedien Wiesbaden, 1995, pp. 257-263.

[16] R. Lanning. "Ethics and self-mastery: Revolution and the fully developed person in the work of Georg Lukács". Science and Society, Vol. 65, No. 3, 2001, p. 340ss.

[17] M. Almási. "Lukács Ontological turn: The Ontology of Social Being”. In: L. Illés; F. József (Eds.), Hungarian studies on Lukács. Budapest: Akadémiai Kiadó, 1993. Vol. 2, p. 559.

[18] F. Benseler. "Der späte Lukács und die subjective Wende im Marxismus". In R. Dannemann, W. Jung (Eds.). Objektive Möglichkeit. Beiträge zu Georg Lukács' "Zur Ontologie des gesellschaftlichen Seins". Opladen: Springer Fachmedien Wiesbaden, 1995, p. 143. 